\title{
The Mind and Stomach at War: Stress and Abdominal Illness in Britain c.1939-1945
}

\author{
IAN MILLER*
}

Medical professionals are often obliged to engage with unforeseen problems during times of conflict. These typically emerge and develop unpredictably, giving rise to spates of internal biological disorders that may affect specific body areas or induce problematic forms of psychological behaviour. The phenomena of shell shock and Gulf War syndrome are prominent historical examples of these, both being conditions not usually witnessed during peacetime. ${ }^{1}$ However, conflict can also generate changes in pre-existing medical complaints. In this article, I suggest that Britain experienced unexpected changes in abdominal problems during the Second World War. ${ }^{2}$ An alarming increase in gastric ailments, most notably dyspepsia, peptic ulcer and duodenal ulcer, was noted from the start of the conflict. There was rising concern in both the government and the medical profession about the anticipated drain on national manpower and military efficiency. I shall relate this to the wider process of the incorporation of psychological medicine into the treatment of conditions of the gastrointestinal tract.

More generally, this paper expands upon suggestions that there exists a wide range of chronic disorders that are of potential importance to historians of medicine. In 1979, G H Brieger complained that the significance of the problematic condition of dyspepsia, or indigestion, had been greatly underrated despite the usefulness that a careful study of it would hold for the enhancement of historical understandings of medical theory and practice. ${ }^{3}$ However, little else was published on the history of stomach problems

\section{(C) Ian Miller 2010}

* Ian Miller, PhD, Centre for the History of Medicine in Ireland, School of History and Archives, University College Dublin, Belfield, Dublin 4, Republic of Ireland; ianmiller_2004@yahoo.co.uk

I would like to thank Professor Michael Worboys, Dr Ian A Burney, Professor Chandu Bardhan, Professor John Pickstone, Dr Roberta Bivins, Dr Rhodri Hayward and Alice Mauger for their comments, feedback and criticism. A draft of this paper was presented at the Wellcome Centre for the History of Medicine at UCL in June 2008. Support for this research was kindly provided by the Bardhan Research and Education Trust (BRET), Rotherham.

\footnotetext{
${ }^{1}$ For shell shock, see Allan Young, The harmony of illusions: inventing post-traumatic stress disorder, Princeton University Press, 1995, pp. 50-85; Anthony Babington, Shell-shock: a history of the changing attitudes to war neurosis, Barnsley, Cooper, 1997; Ben Shephard, A war of nerves: soldiers and psychiatrists in the twentieth century, Cambridge,
}

MA, Harvard University Press, 2001; Peter Leese, Shell shock: traumatic neurosis and the British soldiers of the First World War, New York, Palgrave, 2002. For Gulf War syndrome, see Jeff Wheelwright, The irritable heart: the medical mystery of the Gulf War, New York and London, Norton, 2001, and Martin L Pall, Explaining “unexplained illness”, New York, Harrington Park Press, 2007.

${ }^{2}$ Analysis of the medical complaints of this conflict has been limited so far. Academic attention has mainly concentrated on conflicts such as the First World War. On this gap in the historical literature, Mark Harrison comments that no "other aspect of military life ... has been so poorly served" as that of medicine in the British armed forces during the Second World War. See Mark Harrison, Medicine and victory: British military medicine in the Second World War, Oxford University Press, 2004, p. 1.

${ }^{3}$ G H Brieger, 'Dyspepsia: the American disease? Needs and opportunities for research', in Charles E Rosenberg (ed.), Healing and history: essays for George Rosen, New York, Science History Publications, 1979, pp. 179-90, on pp. 188-9. 


\section{Ian Miller}

until eighteen years later when William F Bynum argued a similar case in Gastroenterology in Britain (1997), an edited volume compiled with the specific aim of outlining some of the area's main individuals, issues and technical developments. He anticipated that future scholars would expand upon what he considered to be a highly significant, if complex, theme. ${ }^{4}$ However, to date, such research has been limited. This article therefore provides one example of how the many experiences of the stomach and its illnesses have occupied prominent positions in society, culture and medicine by locating this organ at the centre of both medical and popular wartime imagination. ${ }^{5}$

\section{The Historical Context of Wartime Medical Complaints}

Modern military combat regularly creates situations that involve possibly the most intense forms of stress known to human beings, not least because of the constant, unpredictable threat to servicemen's lives. The fear of death is heightened by the fact that servicemen are usually in the prime of life, often with wives and small children back home. Groups of medically unexplained symptoms arising during times of conflict have been given the generic names of "war syndromes" and "post-combat disorders". 6 The former is perhaps the most accurate, as many of those who experience war-related medical disorders may not yet have been engaged in fighting but, nevertheless, find themselves unable to function well during training, or to face the prospect of forthcoming battle. ${ }^{7}$

Unexplained wartime medical phenomena might, on the surface, appear to be recent, but comparable conditions date back to at least the nineteenth century. Cardiac problems seem to have been common amongst troops in the American Civil War, and re-emerged in British forces during the First World War, with the phrase "soldier's heart" (or "effort syndrome") being commonly applied as a descriptive term. The suffering of increasing numbers of young soldiers led to the establishment of a military heart hospital, although this development was also a response to mounting concerns that large numbers of disabled soldiers might lead to high levels of post-war disability evaluations and pension awards. ${ }^{8}$ The extent to which the problems experienced in the First World War are

${ }^{4}$ W F Bynum, 'Introduction', in W F Bynum (ed.), Gastroenterology in Britain: historical essays, London, Wellcome Institute for the History of Medicine, 1997 , pp. 5-6, on p. 5.

${ }^{5}$ For more on the history of gastric illnesses, see D A Christie and E M Tansey (eds), Peptic ulcer: rise and fall, London, Wellcome Trust Centre for the History of Medicine at UCL, 2002; Gerald N Grob, 'The rise of peptic ulcer, 1900-1950', Perspect. Biol. Med., 2003, 46 (4): 550-66; Christopher E Forth and Ana Carden-Coyne (eds), Cultures of the abdomen, New York, Palgrave Macmillan, 2005; E A Williams, 'Neuroses of the stomach: eating, gender, and psychopathology in French medicine 1800-1870', Isis, 2007, 98 (1): 54-79; Ian Miller, 'Necessary torture? Digestive physiology, vivisection, the Suffragette movement and responses to new forms of clinical practice in Britian c.1870-1920', J. Hist. Med, Allied Sci., Jul. 2009, 64 (3): 333-72.
${ }^{6}$ See Kenneth C Hyams, F Stephen Wignall and Robert Roswell, 'War syndromes and their evaluation: from the U.S. Civil War to the Persian Gulf War', Ann. Intern. Med., 1996, 125 (5): 398-405; W J Coker, B M Bhatt, N J Blatchley and J T Graham, 'The clinical findings of the first 1000 Gulf War veterans in the Ministry of Defence's medical assessment programme', Br. Med. J., 30 Jan. 1999, 318 (7179): 290-4.

${ }^{7}$ Edgar Jones and Simon Wessely, 'War syndromes: the impact of culture on medically unexplained symptoms', Med. Hist., 2005, 49 (1): 55-78.

${ }^{8}$ The most extensive work on the problem is Charles F Wooley, The irritable heart of soldiers and the origins of Anglo-American cardiology, Aldershot, Ashgate, 2002. See also Joel D Howell, "'Soldier's heart": the redefinition of heart disease and speciality formation in early twentieth-century Great Britain', in 
inter-related with those of the Second World War is debatable, although it has recently been argued that each new post-combat syndrome should not be interpreted as a unique, novel illness, but rather as part of an understandable pattern of normal responses to the physical and psychological anxiety of war. Such an approach might allow these syndromes to be more effectively managed in the future. ${ }^{9}$

Despite the attention paid to unexpected wartime conditions upon their emergence, they have typically remained elusive in nature. Their medically unexplained and syndromic status has invariably resulted in their existence being denied, or at least has encouraged scepticism about the validity of alleged connections between conflict and illness. It has also proved remarkably problematic to attribute them firmly to particular causative factors, as available medical explanations often combine biological symptoms with a variety of cultural or technological forces. For instance, research into military dyspepsia undertaken in the 1980s concluded that it was difficult to correlate its incidence with dietary habits or alcohol, coffee or tobacco consumption. While vague psychoneurotic explanations appeared to dominate, they could not be proved in all patient cases. ${ }^{10}$ The analysis of the medical experiences of the Second World War provides a useful addition to existing analyses of conflict-related medical conditions, as well as showing how wartime circumstances can simultaneously produce biological, political, socio-cultural and military problems.

\section{The Dyspeptic British Soldier}

Compared with the apparent prevalence of cardiac conditions, abdominal complaints went relatively unnoticed during the First World War. Gastritis, for instance, tended to present only as a consequence of gassing, which caused abdominal irritation and varying degrees of internal inflammatory reaction. ${ }^{11}$ Unexpectedly, however, stomach disorders began to affect troops internationally at alarming rates during the Second World War. ${ }^{12}$ This perceived increase in dyspepsia and ulcers defied all existing, logical systems of medical thinking. For instance, few soldiers fighting at Stalingrad developed peptic ulcers, while those further back in the supply line seemed particularly prone. Yet factors on the Eastern Front, including anxiety, cold, fatigue, coarse foods and deficient diets, would in normal situations predispose to the development of ulcers. Initially

W F Bynum, C Lawrence and V Nutton (eds), The emergence of modern cardiology, London, Wellcome Institute for the History of Medicine, 1985, Med. Hist. Suppl. No. 5, pp. 34-52; Christopher Lawrence, 'Moderns and ancients: the "new cardiology" in Britain 1880-1930', in ibid., pp. 1-33. For a discussion of pensions in the First World War, see Peter Barham, Forgotten lunatics of the Great War, New Haven and London, Yale University Press, 2004.

${ }^{9}$ Edgar Jones, Robert Hodgins-Vermaas, Helen McCartney, Brian Everitt, et al., 'Post-combat syndromes from the Boer War to the Gulf War: a cluster analysis of their nature and attribution', $\mathrm{Br}$. Med. J., 9 Feb. 2002, 324 (7333): 321-4.

${ }^{10}$ A Giacosa, S G Sukkar and L Giogoso,

'Dyspepsia among young conscripts: correlations with psychoemotional state and eating habits', J. R. Army Med. Corps, 1987, 133 (1): 59-62.

${ }^{11}$ Arthur Hurst, Medical diseases of war, London, Edward Arnold, 1944, p. 194.

${ }^{12} \mathrm{~A}$ wider discussion of this as an international problem is available in T L Cleave, The saccharine disease, Bristol, John Wright, 1974. Detailed statistics of the British experience can be found in J N Morris and Richard M Titmuss, 'Epidemiology of peptic ulcer vital statistics', Lancet, 30 Dec. 1944, 244 : 841-5. For more on Titmuss, see A Oakley, 'Making medicine social: the case of the two dogs with bent legs', in Dorothy Porter (ed.), Social medicine and medical sociology in the twentieth century, Amsterdam, Rodopi, 1997, pp. 81-96. 


\section{Ian Miller}

the German troops stationed there were able to eat local produce left behind by the Russians but before long the only food available was that growing in the fields. It is claimed that soldiers survived by eating frozen, uncooked turnips and unwashed potatoes picked out of the earth. Despite this, very few men developed ulcers, while soldiers on the supply line with access to a better diet were much more susceptible. The German medical authorities were highly perplexed. ${ }^{13}$

The occurrence of widespread military gastric complaints was also noted early on in the British army, being immediately presented as having possibly disastrous consequences. ${ }^{14}$ It was on the beaches of Dunkirk (26 May to 4 June 1940) that observations were first made regarding widespread ulcer perforations. Men who had thought themselves to be suffering from simple indigestion discovered that they were in fact burdened with severe latent ulcer problems that had been intensified during the evacuation. Reports on effective treatments vary. One soldier is said to have been operated upon in a French field ambulance in a wood near the town, and rapidly recovered. Others, however, were not as lucky, with some soldiers being operated on days after their perforation, after being carried on unsuitable transport, and suffering from peritonitis. ${ }^{15}$

These illnesses were, of course, not new. However, their incidence had risen dramatically throughout the first part of the century. ${ }^{16}$ In 1929 , a striking report was published which claimed that cases of perforated ulcers had risen by over 300 per cent among the male population of Sweden. ${ }^{17}$ In the heated international debate that followed, the most influential British study was that of Denys Jennings, then medical research fellow at Oxford University, who argued in the Lancet in 1940 that peptic and duodenal ulcers had been relatively uncommon in Britain until the start of the twentieth century. He went on to claim that the recent increase in this complaint recorded in hospital statistics could not be fully explained by such factors as the availability of more accurate diagnostic techniques, or improvements in medical services, as had generally been assumed. ${ }^{18}$ The publication of Jennings' work was timely, coinciding as it did with concern that the increase in these conditions in both military and civilian life was exacerbated by the outbreak of war, and corresponding fears of the deleterious impact of this upon national efficiency. ${ }^{19}$ It appeared to medical professionals that biological reactions to

\footnotetext{
${ }^{13}$ Rolf Valentin, Die Krankenbataillone Sonderformationen der deutschen Wehrmacht im Zweiten Weltkrieg, Düsseldorf, Droste Verlag, 1981. The extent to which this problem was an international one is beyond the scope of this article.

${ }^{14}$ For more on British medicine and the military, see Harrison, op. cit., note 2 above.

${ }^{15} \mathrm{G}$ G Taylor, 'The abdominal surgery of total war', Glasgow Med. J., 1942, 19 (6): 123-42, pp. 133-4.

${ }^{16}$ For modern epidemiological literature, see Mervyn Susser and Zena Stein, 'Civilisation and peptic ulcer', Lancet, 20 Jan. 1962, 279: 115-19; J H Baron, 'Peptic ulcer', Mt. Sinai J. Med., Jan. 2000, 67 (1): 58-62; J H Baron and A Sonnenberg, 'Period- and cohort-age contours of death from gastric and duodenal ulcer in New York 1804-1998', Am. J. Gastroenterol., 2001, 96 (10):
}

2887-91; A Sonnenberg, 'Causes underlying the birth-cohort phenomenon of peptic ulcer: analysis of mortality data 1911-2000, England and Wales', Int. J. Epidemiol., 2006, 35 (4): 1090-7.

${ }^{17}$ Bertel Bager, 'Beitrag zur Kenntnis über Vorkommen, Klinik und Behandlung von perforierten Magen- und Duodenalgeschwüren nebst einer Untersuchung über die Spätresultate nach verschiedenen Operationsmethoden', Acta. Chir. Scand., 1929, 64, supp. 11.

${ }^{18}$ Denys Jennings, 'Perforated peptic ulcer: changes in age-incidence and sex-distribution in the last 150 years', Lancet, 2 Mar. 1940, 235: 395-8, 9 Mar.: 444-7. It is worth noting that autopsy studies and GP consultations failed to observe the existence of an ulcer in the early period before technologies such as X-ray were used.

${ }^{19}$ Jones and Wessely, op. cit. note 7 above, p. 55. 
conflict were causing unexplained and unexpected shifts in levels of digestive complaints. Gastric disorders came to be seen as a real and worsening problem.

A number of studies on so-called "military dyspepsia" or "war ulcers" were conducted at the beginning of the war, the most influential being that undertaken by Reginald $\mathrm{T}$ Payne and Charles Newman, both from the British Postgraduate Medical School, who were appointed by the Royal College of Physicians to conduct an investigation between September 1939 and April 1940. They considered the phenomenon to be so urgent that they published an interim report in December 1940 rather than waiting until they had fully collated their findings. Payne and Newman determined that until April 1940, 14.4 per cent of all medical cases evacuated to the United Kingdom from France had a diagnosis of either gastric or duodenal ulcer. Even this figure was thought to be understated as it was likely that many dyspeptic cases had remained behind in French hospitals. ${ }^{20}$ Further studies undertaken that year confirmed these conclusions. In the first six months of 1940, Philip Willcox, medical registrar at St Mary's Hospital, London, examined 260 medical cases sent from France and found that 25 per cent of the patients were suffering from acute gastric conditions. ${ }^{21}$ Medical Officer J Gibson Graham and Captain John Olav Kerr also investigated the problem within various branches of service, including the navy, army, air force and Women's Auxiliary Service, although army patients appeared to them to form the majority of cases. While they did not identify a rise in incidence as such, they were concerned that levels of gastric complaints would increase in proportion to the expected fresh intake into the army. They also found that between April and October 1940, 36 per cent of 980 men were admitted for radiological investigation of digestive complaints in one hospital. ${ }^{22}$ Similarly, C A Hinds-Howell, a medical specialist working with the Royal Army Medical Corps, determined that in one military hospital during 1940, 270 patients were diagnosed with disorders of the stomach, a total of 14.6 per cent of all patients. Of these, 52.7 per cent were suffering from peptic ulcers. ${ }^{23}$

\section{The Postulated Causes of Wartime Dyspepsia}

At the start of the conflict, a number of factors were postulated as being the likely cause of "military dyspepsia". Foremost among these were the internal physiological consequences of external agents such as poor army diet and high levels of tobacco usage. However, these explanations proved to be unsatisfactory and were quickly superseded by interpretations underlining the influence of varieties of psychological anxiety and stress. For instance, Payne and Newman's investigations placed special emphasis upon the inadequacy of military food, denying altogether the possibility that psychological factors might contribute to wartime gastric illness. They deemed army food to be so awful that those soldiers who had lived healthily for years on a careful diet whilst in civilian life appeared unable to cope with a sudden shift towards the heavy, fatty foods provided in military canteens. To make matters worse, it seemed to them that the constant physical

\footnotetext{
${ }^{20}$ Reginald T Payne and Charles Newman, 'Interim report on dyspepsia in the army', Br. Med.J., 14 Dec. 1940, ii: 819-21.

${ }^{21}$ Philip H Wilcox, 'Gastric disorders in the services', Br. Med. J., 22 June 1940, i: 1008-12.
}

\footnotetext{
${ }^{22}$ J Gibson Graham and J D Olav Kerr, 'Digestive disorders in the forces', Br. Med. J., 29 Mar. 1941, i: 473-6.

${ }^{23} \mathrm{C}$ A Hinds-Howell, 'A review of dyspepsia in the army', Br. Med. J., 4 Oct. 1941, ii: 473-4.
} 


\section{Ian Miller}

exercise that was so central to military life inevitably encouraged larger appetites, meaning that soldiers would be inclined to consume greater quantities of the deficient food on offer, thereby increasing their likelihood of developing forms of gastric dysfunction. Accordingly, Payne and Newman's recommendations emphasized the need for the provision of special feeding facilities for soldiers who had already succumbed to dyspepsia and, more generally, an overall improvement in the standard of food so as to halt the rapid development of stomach disorders. This emphasis on physiological factors alone facilitated a relatively simple solution. All that was required, it was suggested, was to improve army cooking. Simultaneously, it seemed probable that those with a weak digestion would be quickly weeded out in the early stages of the war. ${ }^{24}$ However, in reality, and somewhat unexpectedly, army meals improved but stomach problems among the military continued to increase. ${ }^{25}$

A further possible cause of physiological malfunction was tobacco. Its linkage with the gastric system was not new, as investigations had been made throughout the 1930s into the possible interactions between smoking and gastric health. ${ }^{26}$ Willcox's report had drawn particular attention to the role tobacco played in stomach problems, as he had observed that there were only three non-smokers amongst his many gastric patients. To emphasize his point, he noted that one of his duodenal ulcer patients frequently smoked up to sixty cigarettes per day, a habit which he believed was encouraged by the provision of reduced cost tobacco within the Services. ${ }^{27}$ Overall, however, a specific connection between tobacco and wartime dyspepsia proved difficult to determine, and contemporary commentators soon avoided discussing it as a primary cause.

The validity of physiological factors as the sole cause of stomach disorders was challenged by the effect of the conflict on civilians. The civilian experience eventually facilitated the use of psychological explanations. The acknowledgement that the rise in digestive complaints affected civilians as well as the military did much to intensify alarm over the potential damage that the problem could cause to the nation's war effort. The most puzzling occurrences of perforated ulcers were those seemingly closely connected to air raids, although the extent to which these so-called "air raid ulcers" were real or imagined was a contentious issue. Shortly after the beginning of the second week of the London air raids in September 1940, seven patients were admitted to Charing Cross Hospital with perforated peptic ulcers-normally the hospital admitted only one a month. Even that low figure had been expected to drop given that London's population levels had decreased because many people had been evacuated. D N Stewart and D M de R Winser, two students at Charing Cross Hospital, decided to approach eighteen other London hospitals to see if this increase was coincidental. They determined that the total monthly average since 1937 had been around twenty-five cases. Yet in two months

\footnotetext{
${ }^{24}$ Payne and Newman, op. cit. note 20 above.

${ }^{25}$ Henry Tidy, 'Peptic ulcer and dyspepsia in the army', Br. Med. J., 16 Oct. 1943, ii: 473-7, p. 473.

${ }^{26}$ For more on the strong stomach, willpower and military manhood, see Ana Carden-Coyne, 'American guts and military manhood', in Forth and CardenCoyne (eds), op. cit., note 5 above, pp. 71-85. See
}

also O A Trowell, 'The relation of tobacco smoking to the incidence of chronic duodenal ulcer', Lancet, 14 Apr. 1934, 223: 808-9; V S Hodson, 'Duodenal ulcers and cigarette smoking', Lancet, 21 Nov. 1936, 228: $1235-6$.

${ }^{27}$ Wilcox, op. cit., note 21 above. 
alone during 1940, this figure had risen to sixty-four. ${ }^{28}$ A comparison between the military and civilian experiences indicated that diet could not be a shared explanation. In fact, the phenomenon of "air-raid ulcers" completely undermined the validity of concepts of gastric illness, encouraging interpretations that prioritized the role of wartime psychological stress as inducing gastric illness. When perceived in this context, the mystery of the increase in stomach problems in situations such as the evacuation of Dunkirk now seemed to be resolved. Anxiety was an emotion shared by both civilians and fighting men. In the context of total war, conflict now affected even those far from the initial sites of hostilities. Modern warfare, it appeared, had the capacity to exacerbate latent disease, revealing weaknesses in the structural make-up of British society unlikely to be made manifest in peacetime. ${ }^{29}$

\section{The Mind and the Gastrointestinal Tract}

The idea that gastric problems were in some way related to mental activity was far from new. ${ }^{30}$ American physiologists had been interested in the effects of emotion on gastric functions during the previous few decades. ${ }^{31}$ For instance, physiological experiments on the nervous system undertaken in the early 1930s suggested that peptic ulcers could be produced in animals by stimulating the hypothalamic region of the brain. Furthermore, it also appeared that there existed connections between irritative lesions located in the brain stem and the local erosions observed in the stomach that were thought to lead to bleeding or perforating ulcers. ${ }^{32}$ Meanwhile, the work of psychologists such as the Hungarian-American psychoanalyst Franz Alexander became influential. His published research was particularly successful in exploring the dynamic interrelation between mind and body, and emphasized the role of the digestive system. ${ }^{33}$

In 1937, Daniel T Davies, physician to the Royal Free Hospital, London, and A T Macbeth Wilson, assistant physician to the Tavistock Clinic, published a paper on gastric conditions that was frequently referred to in British wartime medical literature.

\footnotetext{
${ }^{28}$ D N Stewart and D M de R Winser, 'Incidence of perforated peptic ulcer: effect of heavy air-raids', Lancet, 28 Feb.1942, 239: 259-61; C C Spicer, D N Stewart and D M de R Winser, 'Perforated peptic ulcer during the period of heavy air-raids', Lancet, 1 Jan. 1944, 243: 14; C F W Illingworth, L D W Scott and R A Jamieson, 'Acute perforated peptic ulcer: frequency and incidence in the West of Scotland', $\mathrm{Br}$. Med. J., 11 Nov. 1944, ii: 617-20.

${ }^{29}$ See, for instance, 'Total war and the individual', Lancet, 1941, 237: 791-2. A contemporary text which dealt with these themes is Martin E Rehfuss, Indigestion: its diagnosis and management, Philadelphia and London, W B

Saunders, 1943, p. 346. For more on total war, see Arthur Marwick (ed.), Total war and social change, Basingstoke, Macmillan, 1988, and Raymond Aron, The century of total war, Lanham, University Press of America, 1985, among others.

${ }^{30}$ It had been a dominant theme in literature on digestion for centuries, and was reasserted in Britain
}

from the 1920s in several texts, including Arthur F Hurst and Matthew J Stewart, Gastric and duodenal ulcer, London and New York, Humphrey Milford, Oxford University Press, 1929.

${ }^{31}$ W B Cannon, 'The influence of emotional states on the functions of the alimentary canal', Am. J. Med. Sci., 1909, 137 (4): 480-6; B A McSwiney, 'Innervation of the stomach', Physio. Rev., 1931, 11 (4): 478-514.

${ }^{32} \mathrm{~J}$ Beattie, 'The relation of the tuber cinereum to gastric and cardiac functions: a preliminary note', Can. Med. Assoc. J., 1932, 26 (3): 278; H Cushing, 'Peptic ulcer and the interbrain,'Surg. Gynecol. Obstet., July 1932, 55 (1): 1-34; Millais Culpin, 'Temperament and digestive disorders', Br. Med. J., 20 July1935, ii: 102-6.

${ }^{33}$ Franz Alexander, 'The influence of psychologic factors upon gastro-intestinal disturbances',

Psychoanal. Q., 1934, 3: 501-88. For more, see idem, Psychosomatic medicine, New York, Norton, 1950. 


\section{Ian Miller}

They aimed to place the aforementioned research of physiologists and psychologists in the 1930s on a sounder statistical basis. To achieve this, they examined 205 peptic ulcer patients, and suggested that certain events causing anxiety had preceded 84 per cent of their cases. The events identified were wide-ranging and included a new job, unemployment, the death of a relative, illness of a partner, "quarrels with the wife", unwanted pregnancy, diagnosis of illness, and even a "bombing exploit". Furthermore, out of fifty-two cases of relapses investigated, forty-two were thought to have occurred just after a further experience of anxiety. For Davies and Wilson, this provided firm evidence that peptic ulcer resulted from the ability of the mind to produce structural change. ${ }^{34} \mathrm{It}$ should be noted that "anxiety" was employed as a somewhat vague term which, in many ways, replaced neurasthenia as an umbrella expression for a variety of mental disorders. Theories of "anxiety neurosis" were typically associated with fear and the instinct of escape, sensations most commonly aroused in situations in which uncertainty and insecurity were prominent. The essential aetiological factors of anxiety appeared strongly linked to more general aspects of the patient's life. ${ }^{35}$

It was not enough, however, to claim that anxiety alone was a causative factor of gastric illness, as large numbers of people exposed to the very same situation would fail to develop this condition. Influenced heavily by Alexander's ideas, Davies and Wilson drew upon the theory that people with particular personalities reacted to anxiety by developing gastric complaints. Such patients became known as "ulcer types", and were considered to be characterized by certain physical and emotional qualities. The type was typically male, had a long thin face, slim build, and boundless energy, combined with restlessness and a tendency to suffer fear or anxiety. ${ }^{36}$ The victim was thought to be able to pass through life happily until he experienced some form of stressful situation, the emergent tension of which would be discharged through the channels of his autonomic nervous system and manifest in the organs of the digestive tract. ${ }^{37}$ Davies and Wilson maintained that these ideas held great clinical potential, suggesting that practitioners should more fully acknowledge the influence of emotional upset as a cause of profound forms of gastric disturbance. Rather than focusing on the specific lesion alone, it was necessary, they argued, to take into account a far wider range of contributing factors, such as the patient's work, responsibilities and environment. ${ }^{38}$

The popularity of concepts stressing the impact of the mind on the gastrointestinal tract also encouraged social scientists to make more broad-based statements about the relationship between the "ulcer type" and his environment. ${ }^{39}$ Most notably, in 1944, the pioneering social researcher Richard Titmuss composed a detailed statistical investigation of the problem with Lieutenant-Colonel Jerry Morris of the Royal Army Medical Corps. They concluded that the economic patterns of unemployment and re-employment

\footnotetext{
${ }^{34}$ Daniel T Davies and A T Macbeth Wilson, 'Observations on the life-history of chronic peptic ulcer', Lancet, 11 Dec. 1937, 230: 1353-60, p. 1353.

${ }^{35}$ G W B James, 'Anxiety neurosis', Lancet, 2 Nov. 1940, 236: 561-4.

${ }^{36}$ For a contemporary statistical evidence of ulcer as a male disease, see Jennings, op. cit., note 18 above.
} 
witnessed in the 1930s were in fact reflected in the epidemiological behaviour of peptic ulcer disease in that period. At the start of the decade, unemployment seemed to have led to a reduction in ulcer mortality as the death rate from the complaint had dropped in those areas particularly affected. However, as economic depression eased and unemployment declined, ulcer mortality rose sharply, apparently as a consequence of the return to work. Titmuss and Morris were most concerned about the rise in city populations during the inter-war period, as such areas, if their observations were correct, were most likely to attract the restless, energetic and ambitious "ulcer types". They recommended, therefore, that the medical profession pay close attention to new nervous strains and stresses that might contribute to an increase in gastric disorders, especially among city dwellers and those working in industry, and use these observations to manage such problems. Clinico-social investigation should, in their view, concentrate particularly on the interplay of constitutional and environmental forces. ${ }^{40}$

Conclusions such as these easily translated into interpretations of wartime gastric complaints. For instance, Payne and Newman's investigations had indicated that the first symptoms of almost 90 per cent of stomach complaints had developed at some point in the 1930s. ${ }^{41}$ Once the likely psychological dimensions became established, it seemed logical to assume that unexpected epidemiological shifts during wartime resulted from some underlying factor that was shared by a high proportion of the British population in the preceding decade. Plausible claims emerged that communal anxiety had laid the groundwork for a sudden expression of widespread, debilitating abdominal conditions. ${ }^{42}$ Accordingly, explanations of current illness increasingly diagnosed the cause as the weakened stomachs of both soldiers and civilians resulting from years of economic hardship and social anxiety. For the advocates of such concepts, the emergence of gastric conditions was a consequence of the entire country suddenly being placed in a state of nervous strain at the outbreak of war. For instance, it was noted that from the summer of 1940 onwards, in addition to extra duties at work, there had been increases in levels of overtime; the consequent lack of sleep, weariness and the irregularity of meal hours were considered to be major contributing factors to the increase in perforating ulcers. ${ }^{43}$

Such beliefs allowed for the possibility that, when confronted by active service life, large numbers of people would find it was simply too much for them. ${ }^{44}$ Although dietary changes, hurried and irregular meals, smoking and a lack of fresh air in blacked-out bedrooms were deemed as unhelpful, factors including a lack of sleep, worry about finances or family members, and even anxiety over the distressed state of mankind were all hypothesized to be possible causes of a rise in problems of the gastrointestinal tract. ${ }^{45}$ The apparent susceptibility of the male population of London to these problems could easily be attributed to the higher frequency of night-time air-raid duties in addition to regular daytime jobs. Moreover, men appeared to smoke more whilst undertaking these night-time roles, further increasing their likelihood of developing abdominal illness. ${ }^{46}$

\footnotetext{
${ }^{40}$ Morris and Titmuss, op. cit., note 12 above.

${ }^{41}$ Payne and Newman, op. cit., note 20 above.

${ }^{42}$ Ibid.

${ }^{43}$ An example of investigators pronouncing these points can be found in Illingworth, Scott and Jamieson, op. cit., note 28 above.
}

\footnotetext{
${ }^{44}$ Rehfuss, op. cit., note 29 above, p. 346.

${ }^{45} \mathrm{R}$ Coope, 'Recent trends in gastro-enterological treatment', Practitioner, 1942, 149 (5): 277-83, p. 277.

${ }^{46} \mathrm{R}$ A Murray Scott, 'Incidence of peptic ulcer', Br. Med. J., 31 Mar. 1945, i: 457.
} 


\section{Ian Miller}

Ostensibly, the "ulcer type" could easily be located in both civilian and military life. In the army, medical authors frequently identified him as the over-conscientious non-commissioned officer, or a driver of a motor lorry, a job entailing prolonged, strained attention and often leading to underlying feelings of anxiety. At home, he was typically thought to be employed as a busy clerk, working long office hours in a responsible position, smoking innumerable cigarettes and eating meals at long or irregular intervals. ${ }^{47}$ Such explanations were easily applicable to the condition of the dyspeptic soldier. Whereas previously, medical discussion about such an individual considered solely his diet and smoking, now the focus was on issues such as his financial worries, anxiety about his return to civilian life and whether his family might be suffering from bombing back home. ${ }^{48}$

\section{The War Effort and Gastric Therapeutics}

It is clear that the popularization of these theories produced profound changes in the treatment of gastric illness. Furthermore, the broader conceptionalization of abdominal disorders promoted by the acceptance of psychological concepts enhanced the wartime influence of those with a particular interest in matters related to digestion and gastric health, especially the leading British gastroenterologist Arthur Hurst. Not only was Hurst greatly interested in the interaction between psychoneuroses and gastric problems but he is also generally considered to have established gastroenterology as a specific field within British medicine, having founded the Gastroenterological Club in $1937 .{ }^{49}$ More generally, the British military was particularly willing to engage with a wide range of medical specialities throughout this war. ${ }^{50}$ As early as 1942 , the manpower situation in Britain was so acute that the country could not afford to operate with the same disregard for causalities as Germany and Russia. ${ }^{51}$ Medicine, therefore, had a vital role to play. This led to the forging of close relationships between medical and combatant officers. It was believed that if the latter were medically minded, great military advantages might result. ${ }^{52}$ In British civilian life, members of the medical profession with a special interest in digestive disorders provided advice on food rationing for ulcer patients, and, in collaboration with the Ministry of Food, on issues such as priority rations of eggs and milk for ulcer patients. ${ }^{53}$ They also advised factory owners on the provision of special food for such sufferers. ${ }^{54}$ It was in the army, however, that the perceived interaction between mind and abdomen was most fully to intrude into therapeutic action.

\footnotetext{
${ }^{47}$ Tidy, op. cit., note 25 above, p. 473 . The reference to drivers probably stems from links made between gastric illness and the medical problems commonly suffered by London bus drivers. See A Bradford Hill, An investigation into the sickness experience of London transport workers, with special reference to digestive disturbances, London, His Majesty's Stationary Office, 1937.

${ }_{48}$ A H Douthwaite, 'Gastro-enterology', Practitioner, 1941, 147 (10): 622-9, p. 624.

${ }^{49}$ For more on Hurst, see Arthur F Hurst, $A$ twentieth century physician: being the reminiscences of Sir Arthur Hurst, London, Edward Arnold, 1949.

${ }^{50}$ See Harrison, op. cit., note 2 above, p. 1.
}

\footnotetext{
${ }^{51}$ See David French, Raising Churchill's army: the British army and the war against Germany 1919-1945, Oxford University Press, 2000, pp. 242-6. For productivity, see John Pickstone, 'Production, community and consumption: the political economy of twentieth-century medicine', in Roger Cooter and John Pickstone (eds), Companion to medicine in the twentieth century, London and New York, Routledge, 2003, pp. 1-20.

${ }^{52}$ Harrison, op. cit., note 2 above, pp. 1-3.

${ }^{53}$ J B Wrathall Rowe, 'Wartime diet for peptic ulcer patients', Br. Med. J., 9 Oct. 1943, ii: 464.

54 J J Horwich, 'Incidence of peptic ulcer', Br. Med. J., 30 Dec. 1944, ii: 866.
} 
Until this stage, gastroenterology had been slow to develop as a specialist field. ${ }^{55}$ This was partly because of a lack of agreement on how best to manage digestive problems. Early-twentieth-century treatment of peptic ulcer, for instance, had been heavily influenced by disagreements between contesting medical specialities. Surgeons and physicians were often sharply divided over therapeutic recommendations, a situation not aided by the existence of a wide range of unproven and debated aetiological theories. Heated arguments proliferated in the medical press regarding the validity of surgical manipulation of abnormalities in the gastric tract, or the value of adjustment of the stomach's acid levels through diet or drugs, both of which had encouraged an emphasis on reductionist treatment. ${ }^{56}$ Psychological medicine, meanwhile, had developed into a specialist field of its own with an increasing influence in many areas of medicine and society. ${ }^{57}$ By the Second World War, the British military were extremely interested in the psychological make-up and well-being of their men. ${ }^{58}$ For example, those with expertise in the gastric system were called on to provide guidance in the enlistment of Royal Air Force pilots, a group considered to be particularly prone to ulcer complaints. Flying had long been observed to have unusual effects upon the gastric tract, and knowledge about matters related to altitude had been developed through experiments with lowpressure chambers, which suggested that a lack of oxygen modified the gastric functions through the automatic nervous system. ${ }^{59}$ The consequences of this could be potentially disastrous. The perforation of an ulcer while the sufferer was flying could cause the stomach's contents to escape into the abdominal cavity, resulting in sudden, excruciating pain that made both flying and landing safely difficult. The first recorded case of socalled "abdominal emergency whilst flying" occurred in June 1930, when a thirtyyear-old RAF corporal based at Reykjavik developed acute abdominal pain while at an altitude of 2000 feet. From this time onwards, fears were heightened that aviation might cause the perforation of latent ulcers. ${ }^{60}$

\footnotetext{
${ }^{55}$ For the development of gastroenterology, see Bynum (ed.), op. cit., note 4 above.

${ }^{56}$ This is a highly complex subject outside the boundaries of this paper, see Grob, op. cit., note 5 above.

${ }^{57}$ See Nikolas S Rose, The psychological complex: psychology, politics and society in England 1869-1939, London, Routledge and Kegan Paul, 1985; Mathew Thomson, Psychological subjects: identity, culture, and health in twentieth-century Britain, Oxford University Press, 2006.

${ }^{58}$ Psychologists, for instance, created instruments intended to screen out men most likely to succumb to battle exhaustion, thus keeping so-called "psychoneurotics" out of combat roles. See J T Copp and B McAndrew, Battle exhaustion: soldiers and psychiatrists in the Canadian army, 1939-1945, Montreal, McGill-Queen's University Press, 1990; Nafsika Thalassis, "The use of intelligence testing in the recruitment of "other ranks" in the armed forces during the Second World War', Hist. Philos. Psychol., 2003, 5 (1): 17-29. For more on psychiatry and war, see Richard A Gabriel, No more heroes:
}

madness and psychiatry in war, New York, Hill and Wang, 1987; Hans Binneveld, From shell shock to combat stress: a comparative history of military psychiatry, Amsterdam University Press, 1997; Joanna Bourke, 'Disciplining the emotions: fear, psychiatry and the Second World War', in Roger Cooter, Mark Harrison and Steve Sturdy (eds), War, medicine and modernity, Stroud, Sutton, 1998; Ben Shephard, 'Pitiless psychology: the role of prevention in British military psychiatry in the Second World War', Hist. Psychiatry, 1999, 10 (4): 491-524; Edgar Jones, 'War and the practice of psychotherapy: the UK experience 1939-1960,' Med. Hist., 2004, 48 (4): 493-510; Nafsika Thalassis, Treating and preventing trauma: British military psychiatry during the Second World War, University of Salford, 2004; eadem,

'Soldiers in psychiatric therapy: the case of

Northfield Military Hospital 1942-46', Soc. Hist. Med., 2007, 20 (2): 351-68.

${ }^{59}$ Rehfuss, op. cit., note 29 above, pp. 359-61.

${ }^{60} \mathrm{~F}$ Twigg, 'Perforation of duodenal ulcer when flying', Br. Med. J., 25 Oct. 1930, ii: 687. 


\section{Ian Miller}

Those with knowledge of the gastric system recommended that the gastric health of individuals should be closely scrutinized throughout the enrolment process, so that physical unsuitability for air service could be recognized at an early stage thus avoiding lengthy and expensive training. It was also suggested that aviation recruiters should never forget that a careful digestive and psychological history was required of all the pilots they engaged. Even those who had recovered from earlier surgical or medical treatment were to be rejected, as their particular personality ensured that they remained prone to recurrence. ${ }^{61}$ Advice was also given on how best to manage the unexpected phenomenon of widespread wartime gastric ulcers. In the early months of conflict, it was common to dismiss soldiers with abdominal complaints. In September 1939, according to Hurst, around 50 per cent of cases were dismissed, with a reduction to 29 per cent in October. Only 7 per cent returned to duty over the following eighteen months. These were often men who insisted on remaining in the army. Hurst was particularly vocal in his recommendations for military admission and dismissal, advising that no one with evidence of ever having had an ulcer should be accepted for service. Even if the patient appeared to be cured, the psychological nature of the condition, he claimed, meant that the ulcer diathesis would remain for life, making him liable to recurrences. The only exceptions Hurst admitted were RAF officers, as, he believed, their personalities were such that they had the willpower to stick to a rigorous dietetic regime. ${ }^{62}$

However, dismissal became an increasingly problematic option as the extent of military stomach complaints became clear, not least because the anticipated increase in gastric disorders seemed to threaten military manpower. It became such an issue that even as early as 1940, the army authorities had sent guidelines to the presidents of military medical boards recommending that chronic cases be transferred to lower classes of service. ${ }^{63}$ If dismissal became perceived as increasingly unfeasible, then one suggestion put forward was to have "ulcer battalions". Essentially, these would consist of groups of soldiers placed together to perform light duties. It was thought that the army could arrange special diets and mealtime routines to decrease sickness levels, and it was also recommended that those with gastric expertise would best be able to manage such a programme. ${ }^{64}$ This scheme was even claimed to be welcomed by the "ulcer type", as these typically had the personality that would be most likely to object to discharge. ${ }^{65}$ Ultimately, the British army did not take up the idea of "ulcer battalions". However, it became increasingly common for men in the forces to be given reduced work levels and to remain in normal service. If their condition failed to improve, it was only then that they might be discharged. One oral history account given to the BBC's recent project WW2 People's War by a naval veteran claimed that his health deteriorated after Dunkirk. He was eventually diagnosed with a duodenal ulcer, and given shore service only. He acted as house help to a lieutenant commander and his wife, typically cooking and keeping the house tidy. His health continued to deteriorate, and he required

\footnotetext{
${ }^{61}$ Rehfuss, op. cit., note 29 above, pp. 356-61.

${ }^{62}$ Hurst, op. cit., note 11 above, pp. 176-8.

${ }^{63}$ William Brockbank, 'The dyspeptic soldier: a record of 931 consecutive cases', Lancet, 10 Jan.1942, 239: 39-42, p. 41.

${ }^{64}$ Tidy, op. cit., note 25 above, p. 473.
}

\footnotetext{
${ }^{65}$ Many of those advocating "ulcer battalions" were particularly interested in their potential for research into the gastric system. See F R Brown, "'Duodenal ulcer battalions"”, Br. Med. J., 31 Oct 1942, ii: 530.
} 
further hospital treatment in October 1943. It was only when he had been given increasingly reduced levels of service that he was medically discharged from the navy, and given work at the Ministry of Supply, a government department supplying the armed services. $^{66}$

If servicemen were expected to continue with their duties, then this necessitated the provision of adequate forms of treatment that dealt with all aspects of their condition. As a consequence, it is clear that, gradually, psychological therapy was given priority over the various forms of physiological therapy. Physicians had often suggested that patients could maintain a robust digestion by carrying small packets of drugs in their pockets, so that they had access to medication at all times. ${ }^{67}$ Members of the surgical community, meanwhile, had advocated their own forms of therapy. Claims that surgery was of particular use were supported by the argument that since operations involved less recovery time they offered a speedier solution than drawn-out forms of medical treatment, a factor that had for long crucially influenced the decisions of patients, particularly of those who hoped to return to work quickly. ${ }^{68}$ Such a concept was eminently transferrable into the military situation where the rapid return of men to active service was of crucial importance. ${ }^{69}$

The increasing popularity of psychological concepts regarding abdominal problems not only resulted in surgery being rejected but also stimulated calls for a complete overhaul of gastric therapy. Those working in the forces, such as Henry Letheby Tidy, a leading author on matters of medicine in wartime, complained that the elaborate schemes of diet available, mostly based upon complex principles of acid reduction, were unsuitable for the treatment of wartime gastric conditions which required urgency and simplicity. Too much attention was being paid to the finer details, he believed, and such methods "should be swept away in the new treatment of wartime". ${ }^{70}$ Surgeons, too, were criticized for being somewhat hasty in their enthusiasm for removing huge parts of the stomach or duodenum, a procedure described by one critic as "so absurd as to be incredible". ${ }^{71}$ By contrast, psychological treatment seemed to offer great potential benefits in this problematic area. Some physicians went so far as to claim that the war was a timely occasion to revolutionize the treatment of peptic ulcers. These included the Liverpool physician Robert Coope, who claimed that wartime shortages of medicines had in fact "purged gastro-intestinal therapeutics of the fussiness and faddiness which have been their particular bane". He went on to state that "even a shortage of newsprint may have compensations if it discourages the hitherto insistent invitations to self-diagnosis and treatment of indigestion or constipation". Rather than subjecting his patient to the many recommended, complex routines of dietetic or drug treatment, he insisted that all that was needed for an ulcer to heal was physical and mental rest with six weeks in bed, followed by a quiet life and a regime to safeguard against relapses. ${ }^{72}$

\footnotetext{
${ }^{66}$ http://www.bbc.co.uk/ww2peopleswar/stories/ 06/a8790906.shtml.

${ }^{67}$ Arthur Hurst, 'Wartime diet for peptic ulcer patients', Br. Med. J., 23 Oct. 1943, ii: 523.

${ }^{68} \mathrm{D}$ C Smith, 'Appendicitis, appendectomy and the surgeon', Bull. Hist. Med., 1996, 70 (3): 414-41.
}

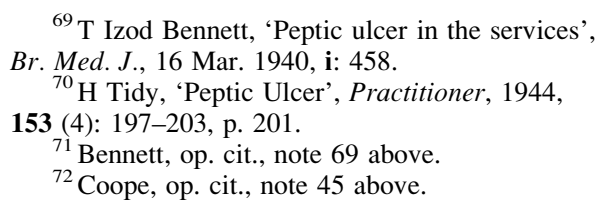




\section{Ian Miller}

In general, the war helped to popularize the idea that gastric conditions could not be resolved by a focus on physiological aspects alone, whether treated by surgery or medicine. It was increasingly deemed necessary to consider the possibility of multiple causes, and to give thought to readjusting the environment and other therapeutic choices, the success of which depended upon the personality of the particular patient. Both gastric specialists and psychiatrists called for a wider application of these ideas. One army psychiatrist, for instance, claimed that, while working at the War Office Selection Board, he had realized the importance of connections between abdominal complaints and personality type, and had attempted to develop a series of studies utilizing psycho-diagnostic methods. He hoped to use his observations to show how the practitioner should incorporate the psychiatric into medical therapeutics, pointing out that rest, sedation and environmental readjustment were more likely to produce good results than any of the forms of treatment in general use. ${ }^{73}$ It is worth noting that psychiatrists never suggested that they should take over treatment completely. It was common for them to argue that psychiatric examination should form part of the clinical examination, but that this did not necessarily depend upon a psychiatrist being present. $^{74}$

A dominant voice in such discussions was that of Hurst. There were, he believed, more gastroenterologists in the army than in civilian practice, and their expertise was being wasted in routine administrative military duties. He went so far as to argue that the "soldier's stomach" was a problem created by bad medical management or delays in treatment rather than by any specific condition of army life, and declared that one way to make savings in manpower was to establish specialist units staffed by experts with gastroenterological experience. His proposed unit was divided into three divisions, one for diagnosis, another for those suffering from organic disease, and a third for sufferers from functional dyspepsia. He anticipated that patients diagnosed with ulcers would be immediately discharged and transferred to civilian hospitals with the hope that they would be rendered useful at home.

Hurst's recommended treatment involved a mixture of medicine and psychotherapy in the expectation that the latter would ensure that only a small number of patients would develop into incurable cases requiring discharge. It was thought that such an environment would promote good psychological health by introducing new ways of thinking, i.e. training the patient in patterns of thinking that would be valuable for the rest of his life. Hurst described it as "preliminary life training". Although he did not entirely deny the importance of providing the patient with information on issues such as the neutralization of stomach acids by foods and drugs, he thought it crucial to stress to the patient the effects that worry and anxiety could have, and to explain the value of this training in upholding the health of the general nervous system through periods of mental and physical rest, congenial surroundings, cheerful companions and appetising food. Furthermore, such treatment rarely required elaborate, specialist methods, meaning that any intelligent and sympathetic medical officer could employ it. ${ }^{75}$

\footnotetext{
${ }^{73}$ B Gilsenan, 'Dyspepsia of peptic ulcer type and its relationship to personality type and anxiety', Practitioner, 1946, 157 (2): 457-8.
} 
As indicated above, those writing about the prevalence of stomach conditions were just as interested in social trends. It is, therefore, unsurprising that Hurst pointed to the analysis of wider social patterns that might lead to anxiety and other varieties of mental problems, insisting that the medical community needed to engage with all social aspects of civilian organization. Rising levels of dyspepsia, ulcers and abdominal cancers could only fall, he suggested, if the patient lived in social conditions free from anxiety. Not only would this automatically reduce smoking and alcohol consumption, but, so Hurst argued, freedom from want would lead to better provision of food, whilst widespread education of young women in domestic service would promote better cooking, improved labour conditions would discourage the bolting of meals, and adequate holiday provision would reduce digestive problems caused by work fatigue and anxiety. He also recommended that every town hospital should be provided with a county annexe for the treatment of chronic diseases as "no greater contribution could be made than this to the cause of national health". ${ }^{76}$

\section{Conclusions}

Was the rise in abdominal illness and its perceived relationship to wartime anxiety real or imagined? This is a difficult question to answer. Today, the treatment of problems such as peptic and duodenal ulcers is primarily concerned with the elimination of bacteria, meaning that epidemiological studies have focused upon the role of the Helicobacter pylori bacterium since its discovery as a causative factor in $1983 .^{77}$ In fact, it has been claimed that an emphasis on the psychological dimensions of peptic and duodenal ulcer disease directed attention away from models that prioritized bacteria as a likely causative factor, and from a treatment that actually worked-antibiotics-with the result that this was delayed until the 1980 s. $^{78}$ Yet, recently, claims have been made that stress is once again an under-rated factor and that the medical profession tends to neglect the influence of psychosocial and socioeconomic behaviour upon infection rates. ${ }^{79}$ In the mid-twentieth century, voices in the medical press persistently attempted to remind readers of the role of psychology in the treatment of gastric ulcers. ${ }^{80}$

Could the problem have been a result of social fears not grounded in biological reality? Critics have claimed that air bombardments of Tokyo, Kobe and Osaka resulted in little in the way of a rise in perforated ulcer incidence, which throws doubt on the interpretation of similar air raids on Britain in the 1940s as a direct cause of gastric illness. ${ }^{81}$ Edward Shorter has suggested that a general fear of crippling abdominal conditions meant that servicemen could more easily gain medical attention. For him, public health fears alert patients and practitioners to particular areas of the body, meaning

\footnotetext{
${ }^{76}$ Ibid., pp. 193-5.

${ }^{77} \mathrm{~J}$ Robin Warren, 'Unidentified curved bacilli on gastric epithelium in active chronic gastritis', Lancet, 4 June 1983, 321: 1273-5.

${ }^{78}$ G D Smith, 'The biopsychosocial approach: a note of caution', in Peter White (ed.), Biopsychosocial medicine: an integrated approach to understanding illness, Oxford University Press, 2005.
}

\footnotetext{
${ }^{79} \mathrm{~S}$ Levenstein, 'The very model of a modern etiology: a biopsychosocial view of peptic ulcer', Psychosom. Med., 2000, 62 (2): 176-85.

${ }^{80} \mathrm{H}$ Spiro, 'Peptic ulcer is not a disease, only a sign! Stress is a factor in more than a few dyspeptics', Psychosom. Med., 2000, 62 (2): 186-7.

${ }^{81}$ Cleave, op. cit., note 12 above, pp. 152-3.
} 


\section{Ian Miller}

that doctors are likely to give consideration to or search for symptoms considered significant at the time, with explanations offered resonating with widely shared beliefs. The selection of symptoms, the weight that is attached to them and the explanations that follow from both doctor and patient are therefore subject to wider cultural forces. ${ }^{82}$ It might be that the actual symptom patterns of war syndromes are very diverse at any given time, and that physicians and patients in fact focus on particular areas of the body. Problems such as effort syndrome endured well into the war but were not perceived with similar levels of concern. Culture offers the ability to provide novel medical explanations that satisfy most of society at any particular time but at the cost of ignoring exceptions and continuities. ${ }^{83}$ As an afternote, I would also suggest that the development of gastroenterology as a field around this period and the importance of the wartime experience to this is unlikely to be coincidental, and that further research possibilities exist for historians of medicine on this topic. ${ }^{84}$

\footnotetext{
${ }^{82}$ E Shorter, 'Paralysis: the rise and fall of a "hysterical" symptom', J. Soc. Hist., 1986, 19 (4): 549-82.
}

${ }^{83}$ Jones and Wessely, op. cit., note 7 above, p. 55.

\footnotetext{
${ }^{84}$ For more on this, see C C Booth, 'Factors influencing the development of gastroenterology in Britain', in Bynum (ed.), op. cit., note 4 above, pp. 96-107.
} 